\title{
A Study on Impact of Motivational Factors on the Growth of Rural Entrepreneurs of Assam
}

\author{
${ }^{1}$ Dipanjan Chakmraborty, ${ }^{2}$ DR. R. Barman \\ ${ }^{1}$ Research Scholar, Assam University, Diphu campus, \\ ${ }^{2}$ Associate Professor and Head, Department of Commerce Assam University, Diphu campus
}

\begin{abstract}
India may be one of the fastest growing economies of the world today. But there is a large area of darkness in the rural hinterland. 69 percent of our population lives in the rural areas and majority of people in rural areas depend on agriculture for their livelihood. About 7 crore people are without employment as per the National sample survey report published in 2012. The share of agriculture has increasingly declined in recent years resulting in continuous migration from the rural to urban areas in search of better employment opportunities and living standard. Thus, there is need to strengthen employment opportunities in the rural areas by promoting rural entrepreneurship. The same scenario prevails in the state of Assam too. The economy of the state is heavily dependent on agriculture. The cultivators and agricultural labourers' constitute $64 \%$ of the total working population.Inspite of being endowed with immense potential for development of resource- based and demand-based industries, the pace of rural industrialization in Assam has not been satisfactory. The study is made in the Sonitpur district of Assam based on data collected from 288 entrepreneurs through structured questionnaire. The findings suggest that the entrepreneurs were primarily motivated by the need for self employment, eagerness to make money, need for independence. The study also provides new insights on the impact assessment of EDP on rural micro entrepreneurs in the district. It concludes with few suggestions based on findings of the study.
\end{abstract}

Key Words: Rural entrepreneurship, rural industrialisation, micro entrepreneurs

\section{Introduction}

India's heart lies in villages. The development of country like India can be achieved only by transforming the rural areas. The progress in growth and development that does not fulfill the needs of rural area and its people, especially the poor, cannot be claimed as development in India. (Harendra Sinha, 2010). India may be one of the fastest growing economies of the world today; but there is a large area of darkness in the rural hinterland. 69 percent of our population lives in the rural areas and majority of people in rural areas depend on agriculture for their livelihood. About 7 crore people are without employment as per the National sample survey report published in 2012. The share of agriculture and allied sectors in the GDP has been reduced to 14 percent. The census 2011 estimates that 83 million people continue to live below poverty line in rural India. The total number of villages in India has increased from 6,38,588 (census 2001) to 6.40,867(2011) an increase of 2279 villages.(Dwaraka Nath-2013) The proportion of people living below the poverty line in rural areas can be reduced significantly by encouraging entrepreneurial activities. Apart from increasing the income at village level, the rural entrepreneurship can significantly contribute to the national income of the country. Rural entrepreneurship can play an important role in ensuring the development of a village through the accrual of intrinsic and extrinsic benefits to the villagers

Assam, a part of north-east India, is one of the most culturally and geographically distinct parts of the country. $86 \%$ of Assam's population lives in villages. Agriculture accounts for more than one-third of Assam's income and employs $69 \%$ of the workforce. Average literacy rate in rural areas is $70.44 \%$.The unemployment problem is more pronounced in the rural areas of Assam as there is a gradual increase in educated unemployed. (Economic Survey, Assam 2011). Assam which constitute 20.85 percent of total population, account for 13 percent of the unemployment.

\section{Rural Entrepreneurship And Rural Entrepreneurs}

The term rural entrepreneurship refers to the self employment programs exclusively meant for rural people.(SangramKeshari-2006) .In other words, establishing industrial and business units in the rural areas refers to rural entrepreneurship. Rural entrepreneurship implies rural industrialisation. Rural Entrepreneurship can be defined as entrepreneurship emerging at village level which can take place in a variety of fields of endeavour such as business, industry, agriculture and acts as a potent factor for economic development. The notion of "rural entrepreneurship" is not limited to agriculture and related activities such as food processing, but rather it covers industrial development in general. In addition, the concept is not restricted to villages but also 
pertains to small towns and surrounding areas. Broadly speaking, the concept relates to areas where industry and tourism are not developed. (KulawczukPrzemyslaw-2010)

Rural entrepreneurs may be defined as "Any individual or group of persons carrying out economic activity with profit motive in the rural areas with or without any proper infrastructure facilities can be termed as rural entrepreneurs." Rural entrepreneurs are broadly classified into Agricultural Entrepreneurs, Micro Entrepreneurs, Small Business entrepreneur and Rural Artisans. (Vasant Desai-2010)

\section{Literature Review}

The study of Ajit Kanitkar (1994) aims at understands the emergence of successful entrepreneurs and owners of micro-enterprises in rural India. Based on the case studies of 86 village-based entrepreneurs drawn from different regions of India, the article examines that socio-economic profile of the entrepreneurs, their motivation for shifting from an agriculture-based occupation to a non-farm activity, their approach to raising resources for their enterprises and the factors that facilitated entry of the village based entrepreneurs in to a business activity.

Orhan and Scott (2001) surveyed 25 women entrepreneurs to explore the reasons that motivate women to enter in to business. They used the qualititative research technique; the in-depth interview method to develop a model.Reserach indicated many motivating factors classified as influence of environment, push factors and pull factors. 'Dynastic compliance' and 'natural succession' were environmental influences, Push factors were 'no other choice' and forced entrepreneurs' Pull factors included 'informed entrepreneurs' and pure entrepreneurs'.

Sarri \& Trihopoulou (2005) had examined personal characteristics and motivations of women entrepreneurs in Greece. The study revealed that the education level of the respondents was high, mostly women were married and had children. There was also a tendency to enter in to business in old age. The women in Greece were mostly motivated by pull factors like self- fulfillment, need for creativity and independence.

Mishra \& Bal (1997) conducted an empirical study on entrepreneurial motivation in seven districts of Orissa. The author had analysed the data collected from a sample of 110 entrepreneurs. A large number of factors-financial, institutional, cultural and political structure, overall socio-economic background, government policies, individuals' preferences and willingness-were found responsible for entrepreneurial activities in any country at any time. The behaviour of human beings is controlled by their urges, drives, desires, and needs which are backed by motivational factors for entering in to entrepreneurial business. Dissatisfaction with previous job, dependency situation, insistence by elders were strong compelling factors. Among the internal and external factors, business experience and liberal financial help from financial institutions emerged as major factors. Availability of raw materials, marketing support from government, accessibility of infrastructure and technology, moral support were some of other major motivating factors.

Sophia Stathopoulou Demetrios Psaltopoulos and Dimitris Skuras (2004) provides an integrated view of rural entrepreneurship and sets the agenda for future research in the area. Rural entrepreneurship is depicted as a three-stage sequential process highly influenced by specific territorial characteristics. The proposed research agenda addresses issues related to theoretical studies concerning entrepreneurial processes in rural areas and more applied issues concerning the formulation of integrated and competent policies support entrepreneurship in such areas.

Kaippachery (2005) analysed the impact of economic reforms structure schedule on the 82 rural smallscale enterprises(RSSEs) located in kannur district of kerala.The results found negligible impact of the reforms on employment, earning capacity and availability of raw material whereas output,productivity,market access, diversification,safety of labour and capital were found to be more vulnerable to unsustanibilty.To support economically unsustainable RSSEs, the study suggested development of rural financial markets, trades fares,advertisement,displays etc.,to improve marketing of rural industrial products ,cost reduction, improvements in the quality of products, cost reduction, improvement in the quality of products and dissemination of market information to customers

Nicola Mecchari, and Gianluigi Pelloni (2006) presents and analyses the results emerging from a questionnaire submitted to a sample of 123 rural entrepreneurs and business in a mountainous area of central Italy. In particular, they test for six hypotheses concerning the correlation between different factors, reflecting entrepreneur and business specific characteristics, and the adoption of instruments of institutional assistance. Their study also examines and proposes potential polices for fostering entrepreneurship and the development of the rural region under study.

Ram Krishna Mandal (2007) in his paper encompasses the present scenario of Khadi and Village Industries in the North east States, particularly Arunachal Pradesh, in relation to growth, development, problems and solutions. The author opined that top priority should be given to those small scale industries like KVIs which need light machine tools and other equipments in order to produce qualitative products because today, a state's progress is measured by the quality of goods it produces 
Srivastava and Syngkon (2008) study makes an in depth analysis of the development of small scale industrial (SSI) sector in the rural areas of the states of NER of India. The study also focuses specifically on the role and profile of entrepreneurs. The findings reveal that the manufacturing, assembling, processing, activity is the dominant group among the various SSIs activities in the NE states in rural and urban areas. It is observed that in most of the North Eastern states, concentration and growth of SSI activities is higher in rural areas than in urban areas. The study also brings to light the rising number of women and tribal entrepreneurs in the region.

Sharmina Afrin, Nazrul Islam and Shahid Uddin (2008) Ahmed in their study tried to identify the factors related to the development of entrepreneurship among the rural women borrowers through micro credit programs. The findings shows that the financial management skills and the group identify of the women borrowers have significant relationship with the development of rural women entrepreneurship in Bangladesh

Khanka (2009) conducted a survey of 248 first generation entrepreneurs in Assam in NE India to understand their entrepreneurial motivation. The study clearly showed that the entrepreneurs were primarily motivated by the need for economic achievement, personal growth, autonomy and recognition. The desire to contribute to the community was not found to be an important reason to become an entrepreneur. The study did not reveal any significant difference in the motivations of men and women entrepreneurs.

A paper on" Rural entrepreneurship Development Programme- Am impact Assessment" stated that a carefully designed selection process to identify and choose only interested and potential youth would make the REDP a success. Thus there is a need to have a proactive role by government agencies like District Industries Centre (DIC), Banks, and NGOs, in mapping of potential and identifying borrowers. They will impart entrepreneurial skills and provide enabling environment for conducting REDPs.

Gangadhar Banerjee and Srijeet banerji (2011) conducted a study on rural entrepreneurship development programme - an impact assessment in seven states of India namely Andhra Pradesh, Bihar, Chhattisgarh,Himachal Pradesh, Odisha, Uttar Pradesh and west Bengal. The programme were conducted through Entrepreneurship Development Institute, Voluntary associations, Non- Governmental organisations for providing sustainable employment and income opportunities in rural areas. The study reveals that REDPs is an efficient instrument in creating income and employment opportunities for the rural youth, especially the women in rural and semi-urban areas. The study recommends that there is a need to adopt a comprehensive strategy to cover adequate number of potential entrepreneurs under REDP through EDIs/RUDSET type institutes and select capable VAs/NGOs to operationalise the strategy.

Jyoti kumar and Lalhunthara (2012), in their study on socio-economic background of Micro entrepreneurs in Aizawl district, Mizoram found that Education, experience, age and family play an important role in shaping the entrepreneurial ambition of the aspirant. It was found that nearly one-fourth of entrepreneurs were females. Their study also reveals that entrepreneurs were engaged in different lines of business activities ranging from tailoring to food processing, involving complex technologies and different skills sets.

\section{Statement Of The Problem}

Inspite of the fact that rural micro and small entrepreneurship has a long history of development and its importance in national economic scene is steadily growing, there is very little literature providing an objective assessment of rural micro and small scale entrepreneurship. The literature, available in mostly governments reports and more often than not studies by administration involved in formulation of policies for its implementation. This kind of literature is likely to lack objectivity and impartial assessment of the role of micro and small scale entrepreneurship in the country. There is a need for many more studies on rural entrepreneurship because of variations in geographic, social, cultural, political and economic conditions from state to state and from region to region within a state. There is also need to throw light on the factors that motivate the rural micro entrepreneurs to establish their units. This observation is more relevant in the context of rural micro and small scale entrepreneurship in the district of Sonitpur, Assam, whose exact place of importance in the overall economic system and the direction of growth are not properly assessed. Sonitpur district is the industrially backward area though it has been endowed with several facilities beneficial for growth of rural entrepreneurs compared to other districts in Assam. So, it is felt that this district is ideally suited for a study on rural entrepreneurship.

\section{Objective And Hypothesis}

The main objective of this study is to examine the motivational factors of rural entrepreneurs in the sonitpur district of Assam. 


\section{Hypothesis of the study}

That various entrepreneurial development programmes and policies are inadequate to motivate rural entrepreneurs

\section{Methodology}

The present study was carried out in Sonitpur district of Assam and Size of sample was determined by applying the Krejcie and Morgan's formula of "Determining Sample Size for Research Activities" from a total population $(\mathrm{N}=1150)$. Accordingly the number of sample size was found to be 288 . These 288 samples were drawn considering 14 blocks as a whole population by the simple random sampling method. The sample has been selected on the basis of Tippet's random number table and fortunately from all blocks more or less equal number of sample has generated. The data for the study was collected both from primary and secondary sources. Primary data was collected from selected rural entrepreneurs through formal interview schedule. Secondary data was collected from the sources like DICs and KVIB and from published data in books, journals, magazines, websites etc.Statistical tools and techniques were used for producing the results from the collected data. The analyses of data were carried out by simple statistical techniques' like percentages, mean, standard deviation coefficient of variation.Inter-variable relationships have been established wherever possible by carrying out cross tabulation of the available data. Inferences drawn as a result of analysis of data have been interpreted keeping in view the objectives of the study.

\section{Period of study}

The study was carried out from April 2000 to march 2010 for primary data collection. The reference period of survey was 2000-2010

\section{Factors Influencing The Idea Of Starting The Enterprise \\ VII. Results And Discussion}

An entrepreneur is motivated to set up an enterprise or take up economic activity for various reasons. This study proposes to enquire into entrepreneurial motives and facilitating factors and motivators in the case of entrepreneurs In this study each rural entrepreneur was asked to select the most important factor which stimulates him/her to become an entrepreneur. Accordingly they stated the factor as----- Self employment, continue the same family business, Dissatisfaction with the present job, Eagerness to make money, Gain social prestige, Make use of technical and professional skill, Need for independence, Success stories of other entrepreneurs and any other factors. It is also impossible to prepare a long list of many possible factors so to meet such contingencies, the $9^{\text {th }}$ factor titled "any other factor" is included in the list. These motivational factors listed in table 1 separately for two categories - manufacturing and service. The table shows that 32.3 percent of the rural entrepreneurs have started the enterprise to be self employed,

Table 1: Factors Influencing The Idea Of Starting The Enterprise

\begin{tabular}{|c|c|c|c|c|c|c|}
\hline \multirow{2}{*}{ FACTORS } & \multicolumn{2}{|c|}{ Manufacturing } & \multicolumn{2}{|c|}{ Service } & \multicolumn{2}{c|}{ Total } \\
\cline { 2 - 7 } & No & Percentage & No & Percentage & No & Percentage \\
\hline Self employment & 59 & 30.3 & 34 & 36.6 & 93 & 32.3 \\
\hline Continue the same family business & 26 & 13.3 & 8 & 8.6 & 34 & 11.8 \\
\hline Dissatisfaction with the present job & 15 & 7.7 & 7 & 7.5 & 22 & 7.6 \\
\hline Eagerness to make money & 33 & 16.9 & 17 & 18.3 & 50 & 17.4 \\
\hline Gain social prestige & 11 & 5.6 & 5 & 5.4 & 16 & 5.6 \\
\hline $\begin{array}{c}\text { Make use of technical and } \\
\text { professional skill }\end{array}$ & 12 & 6.2 & 2 & 2.2 & 14 & 4.9 \\
\hline $\begin{array}{c}\text { Need for independence } \\
\text { Success stories of other } \\
\text { entrepreneurs }\end{array}$ & 24 & 12.3 & 17 & 18.3 & 41 & 14.2 \\
\hline Any Other factors & 8 & 3.6 & 2 & 2.2 & 9 & 3.1 \\
\hline Total & 195 & 100.00 & 93 & 100.00 & 288 & 100.00 \\
\hline
\end{tabular}

Source: Filed survey

*Other factors: EDP, family environment, availability of government subsidies

17.4 percent of rural entrepreneurs started their enterprise to make money, 14.2 percent of rural entrepreneurs stated the desire to lead an independent life as the reason.11.4 percent wanted to continue the family business whereas 7.6 percent were dissatisfied with the present job, 5.6 percent of the rural entrepreneurs started the enterprise to earn social prestige from the society, 4.9 percent were joined in to the business to utilize their technical and professional skill, whereas success stories also influenced to the extent of 3.1 percent. In case 
of 3 Percent of rural entrepreneurs factors such as EDP, family environment, availability of government subsidies has also worked as motivating factors to start an enterprise

\section{Motivators In Starting The Enterprise}

Motivators play prominent role in the establishment of any enterprise. They are the persons, relatives, friend's parents, spouse etc who motivate any person to set up an enterprise. They are helpful in giving idea about how the business should be started. Hence, it becomes necessary to find the motivators in launching the projects/enterprises. Once an entrepreneur has been convinced that he should take up some gainful activity, then he has to be motivated and nurtured by some well-wishers.the detailed analysis of various motivators has been presented in table-2

Source: Filed survey

Table 2: Motivators In Starting The Enterprise

\begin{tabular}{|c|c|c|c|c|c|c|}
\hline \multirow{2}{*}{ Motivators } & \multicolumn{2}{|c|}{ Manufacturing } & \multicolumn{2}{c|}{ Service } & \multicolumn{2}{c|}{ Total } \\
\cline { 2 - 7 } & No & Percentage & No & Percentage & No & Percentage \\
\hline Self & 71 & 36.4 & 38 & 40.9 & 109 & 37.8 \\
\hline Spouse & 32 & 16.4 & 14 & 15.1 & 46 & 16.0 \\
\hline Friends & 31 & 15.9 & 12 & 12.9 & 43 & 14.9 \\
\hline Relatives & 24 & 12.3 & 9 & 9.7 & 33 & 11.5 \\
\hline Family members & 37 & 19.0 & 20 & 21.5 & 57 & 19.8 \\
\hline Total & 195 & 100.00 & 93 & 100.00 & 288 & 100.00 \\
\hline
\end{tabular}

Table 2. Shows that 37.8 percent rural entrepreneurs were self motivated. 19.8 percent were motivated by their family members, 16 percent were motivated by their spouse. Friends had motivated rural entrepreneurs to the extent of 14.9 percent while Relatives had motivated rural entrepreneurs the extent of 11.5 percent.

It is very interesting to note that self-motivation is dominant among all the motivators. It could be concluded that entrepreneurship is the result of an encouragement and active support of the wife and family members apart from the individual initiative. It can be inferred that initiative was very much acknowledged and encouraged by spouse, friends, and relatives and family members.

\section{Reasons For Choosing The Present Line Of Activity}

Decision regarding the selection of a particular line of activity is an onerous task. Because the ultimate success of an enterprise perhaps depends upon this decision. So this crucial decision of selecting a line of activity should be taken a good deal of deliberation. No other decision may be so important as the implementation of the right kind of policies and planning. Decision making in such matters requires much expertise as micro and small industry is one area where it is impossible to track a mistake once it is ignored for a long time after it has been committed. Micro and Small enterprise contributes in a big way, offering productivity and quality at par with medium industries. This sector has grown in the country in terms of production, exports, quality and is still growing micro and small industries now provide 40 percent of natural gross domestic product a vast change as compared to 1950 's. Hence, it was thought to be appropriate to examine the reasons that influenced the rural entrepreneurs for choosing a present line of economic activity.

TABLE 3: REASONS FOR CHOOSING THE PRESENT LINE OF ACTIVITY

\begin{tabular}{|c|c|c|c|c|c|c|}
\hline \multirow[t]{2}{*}{ Reasons } & \multicolumn{2}{|c|}{ Manufacturing } & \multicolumn{2}{|c|}{ Service } & \multicolumn{2}{|c|}{ Total } \\
\hline & No & Percentage & No & Percentage & No & Percentage \\
\hline Ease to start business & 56 & 28.7 & 33 & 35.5 & 89 & 30.9 \\
\hline High profitability & 48 & 24.6 & 20 & 21.5 & 68 & 23.6 \\
\hline Less competition & 45 & 23.1 & 21 & 22.6 & 66 & 22.9 \\
\hline Previous experience & 21 & 10.8 & 4 & 4.3 & 25 & 8.7 \\
\hline Easy marketability & 18 & 9.2 & 12 & 12.9 & 30 & 10.4 \\
\hline Others & 7 & 3.6 & 3 & 3.2 & 10 & 3.5 \\
\hline Total & 195 & 100.00 & 93 & 100.00 & 288 & 100.00 \\
\hline Value of chi-square & & & 072 & & & \\
\hline Table value at 0.05 level & & & 1.07 & & & \\
\hline
\end{tabular}

Source: Filed survey

*others include workers easily available, capital in hand etc. 
Table 3 shows that easiness to set up an enterprise influenced the entrepreneurs much in their choice of the present line of activity 30.9 percent of rural entrepreneurs had listed their reason as easy to start business as the main reason to have influenced them. The second main reason which had influenced them was higher margin of profit with a overall score of 23.6 percent.22.9 percent of the rural entrepreneur had stated that less competition was the reason for choosing the present line of activity, 10.4 percent of the entrepreneurs easy marketability of the products was the reason.22.9 percent has selected their line of activity because of previous experience in the field. Only 3.5 percent of the entrepreneurs had selected their line of activity because of workers easily available, capital in hand etc.

Selecting a present line of activity on the grounds of easy entry/ start up was not a sound one. If the entrepreneurs hesitated to take more pains in the beginning, then they might have to pay price for it in the long run. Of course it did not mean that rural entrepreneur were likely to err in all the cases when the decision of the choice of the line of activity was taken on such grounds mentioned through the table no. 3. A sub-hypothesis was formed to show the association between the reasons for choice at present line of activity and nature of firm. It is evident from table 4.3 that the value of Chi-square was found to be significant at $0.05 \%$ level. This shows that there is a significant relationship between the reasons for choice at present line of activity and nature of firm.

\section{Reasons For Locating Enterprise In His/Her Area}

The location of an enterprise is most key factor, which can truly indicate the success or failure of any unit in the very beginning. Hence, portraying the reasons for locating the enterprise in Sonitpur district by rural entrepreneurs in this aspect is considered important. The options were carefully selected keeping in mind the conditions of rural entrepreneurs from the different sectors.

The table portrayed that the consideration of hometown was important for selecting the present location for 22.9 percent of the rural entrepreneur. 16 percent selected the place because of the resources available at lesser cost .Availability of raw materials and non-existence of similar unit was the third important factors with 14.9 percent each.13.9 percent selected the place due to availability of labour .9 .7 percent of the rural entrepreneurs have chosen the place because of the nearness to market availability of the plot and government incentives.

TABLE 4: REASONS FOR CHOOSING THE PRESENT LINE OF ACTIVITY

\begin{tabular}{|c|c|c|c|c|c|c|}
\hline \multirow[t]{2}{*}{ Reasons } & \multicolumn{2}{|c|}{ Manufacturing } & \multicolumn{2}{|c|}{ Service } & \multicolumn{2}{|c|}{ Total } \\
\hline & No & Percentage & No & Percentage & No & Percentage \\
\hline Birth Place & 51 & 26.2 & 15 & 16.1 & 66 & 22.9 \\
\hline Low cost resources & 36 & 18.5 & 10 & 10.8 & 46 & 16.0 \\
\hline $\begin{array}{c}\text { Availability of raw } \\
\text { materials }\end{array}$ & 23 & 11.8 & 20 & 21.5 & 43 & 14.9 \\
\hline Availability of labour & 28 & 14.4 & 12 & 12.9 & 40 & 13.9 \\
\hline $\begin{array}{l}\text { Infrastructural } \\
\text { facilities }\end{array}$ & 17 & 8.7 & 5 & 5.4 & 22 & 7.6 \\
\hline $\begin{array}{l}\text { Non-existence of } \\
\text { similar unit }\end{array}$ & 27 & 13.8 & 16 & 17.2 & 43 & 14.9 \\
\hline Others & 13 & 6.7 & 15 & 16.1 & 28 & 9.7 \\
\hline Total & 195 & 100.00 & 93 & 100.00 & 288 & 100.00 \\
\hline Value of chi-square & \multicolumn{6}{|c|}{16.372} \\
\hline $\begin{array}{c}\text { Table value at } 0.05 \\
\text { level }\end{array}$ & \multicolumn{6}{|c|}{12.53} \\
\hline
\end{tabular}

Source: Filed survey

*Others includes nearness to market, availability of own plot\& shop etc, government incentives

It can thus be concluded that consideration of home town was the major reason for the location of the enterprise in Sonitpur district of Assam. A sub-hypothesis was formed to show the association between the reasons for locating the enterprise in Sonitpur and nature of firm.It is evident from table 4.4 that the value of Chi-square was found to be significant at $0.05 \%$ level. This shows that there is a significant relationship between the reasons for locating the enterprise in Sonitpur and nature of the firm.

\section{Initial Sources Of Finance To Start The Business}

Apart from the non-financial stimulants, it would be germane to know the role of initial sources of finance in stimulating entrepreneurial activity. The initial sources of finance are shown in table 5.The figure 5 
shows that 44.8 percent of the rural entrepreneurs had raised the finance support from family members, 40 percent from commercial banks, 8.4 percent from government

TABLE 5: INITIAL SOURCES OF FINANCE TO START THE BUSINESS

\begin{tabular}{|c|c|c|c|c|c|c|}
\hline \multirow{2}{*}{ Reasons } & \multicolumn{2}{|c|}{ Manufacturing } & \multicolumn{2}{|c|}{ Service } & \multicolumn{2}{c|}{ Total } \\
\cline { 2 - 7 } & No & Percentage & No & Percentage & No & Percentage \\
\hline Family members & 92 & 37.5 & 37 & 45.2 & 129 & 44.8 \\
\hline Government agency & 15 & 7.7 & 9 & 9.7 & 24 & 20 \\
\hline Money lenders \& others & 15 & 7.7 & 5 & 5.4 & 115 & 40.0 \\
\hline Commercial banks & 73 & 47.2 & 42 & 39.8 & 288 & 100.00 \\
\hline Total & 195 & 100.00 & 93 & 100.00 & & 20 \\
\hline
\end{tabular}

\section{Source Filed survey}

Agencies and remaining 6.9 percent from money lenders. The financial help from the family members of the rural entrepreneur is to be considered as an important and strategic one. Firstly, it indicates the confidence of the family in the capabilities of the rural entrepreneur and profitability of the activity. Secondly, it indicates the preparedness of the family to risks its savings in an entrepreneurial activity. On the top of these, it is a torch bearer in shaping the entrepreneur's new career. From this, it is acknowledged that family members are encouraging the entrepreneurial development.

\section{Participation In Edp}

Training is the need of the hour especially for the business enterprise. As it plays a significant role in entrepreneurship development; it is required for both potential and existing entrepreneurs. The rural entrepreneurs were asked to indicate whether they had participated in any EDP/training programme from any institutions supporting entrepreneurship. The responses are shown in table 6. Of the sample, 157 rural entrepreneurs participated in EDP before launching their enterprise. It is evident from table 6 that 131 rural entrepreneurs had not attended any training programme before starting their enterprise. The training was in the areas of marketing management, financial management, quality control, technical support, sales technique etc.

TABLE 6: PARTICIPATION IN EDP

\begin{tabular}{|c|c|c|c|c|c|c|}
\hline Undergone EDP training & \multicolumn{2}{|c|}{ Manufacturing } & \multicolumn{2}{c|}{ Service } & \multicolumn{2}{c|}{ Total } \\
\cline { 2 - 7 } & No & Percentage & No & Percentage & No & Percentage \\
\hline Yes & 102 & 52.3 & 55 & 59.1 & 157 & 54.5 \\
\hline No & 93 & 47.7 & 38 & 40.9 & 131 & 45.5 \\
\hline Total & 195 & 100.00 & 93 & 100.00 & 288 & 100.00 \\
\hline
\end{tabular}

Source Filed survey

\section{Major Expectations And Extent Of Their Fulfillment From Edps}

The success of training programme for developing entrepreneurship depends upon qualities and skills of trainers. Training institutions should possess competent, devoted and motivated faculty for imparting training skills. In this study entrepreneurs were asked to comment on their major expectation, i.e., at least three in different rank as satisfied, satisfied to some extent and not-satisfied at all.

Table 7 shows expectation of 157 numbers of respondents in sonitpur district. Most of the respondents had more than one expectation from the programmes. Important expectations are expected knowledge about starting an enterprise or taking up an economic activity after training, knowledge about MSME, knowledge about finance, assistance in selecting a project, marketing support, knowledge of technical know-how, grant of subsidy, knowledge of management, knowledge about incentives, and knowledge about project report.

Out of 157 respondents (SL-1) only $44(28 \%)$ admitted that training had helped them in setting up an enterprise, 71(45\%) satisfied to some extent and $42(30 \%)$ entrepreneurs felt that training could not help them in setting up an enterprise or taking up an economic activity. So they were not satisfied at all. Out of 157 ( SL-2) respondents 66 (42\%) had admitted that training programme had helped them in getting the knowledge about MSME and hence satisfied,54 (34\%) respondents satisfied to some extent and 37(24\%) respondents were not satisfied from the programme.

Respondents (SL-3) who expected knowledge about finance, 89 (57\%) felt that training had helped in getting knowledge about finance and hence satisfied.48 respondents (31\%) felt that training could helped them partly and remaining $20(12 \%)$ were not satisfied at all. As regards selection of project, out of 157 respondents, 
only $26(17 \%)$ gave credit to training organisation in finalizing report, 55 (35\%)have been satisfied to some extent and other 76(48\%) felt that training could not help them in securing knowledge about project, so they were not satisfied.

Marketing expectation (SL-5) reveals that 28 respondents gave satisfactory opinion, 48 respondents satisfied to some extent and 81 respondents were not satisfied. Expectation like knowledge of technical knowhow could hardly satisfy the respondents. Out of 157 respondents (SL-6) Only 28 respondents satisfied and 10 respondents satisfied to some extent and 119 respondents were not satisfied at all. All most all were of the view that major emphasis remained on imparting theoretical inputs and practical tips were missing in all case. In such cases participants failed to develop competency from a techno- economic view point and were totally unsatisfied.

Out of 157 respondents (SL-7), who expected knowledge about subsidy, 54 were satisfied. 24 were satisfied to limited extent and other 79 respondents felt that trainers were not able to give information about various subsidy scheme. So they were not satisfied.

157 respondents also felt that training organisations were not able to fulfill their expectation like managing an enterprise. Out of 157 respondents (SL-8),40 (25\%) admitted that training programme had helped them in acquiring knowledge about management and hence satisfied.54 (34\%) were satisfied to some extent and remaining $63(41 \%)$ were not satisfied at all about knowledge of management.

Out of 157 respondents ( SL-9) who expected knowledge about incentives it was found that 46 were satisfied,42 were satisfied to some extent and 69 respondents were felt that training was training was of no use in acquiring knowledge about various incentives and hence not satisfied at all.

In preparation of project report (SL-10) only 39 (25\%) was 'satisfied', 53(34\%) 'Satisfied to some extent' and 65(41\%) respondents opined that they did not know how to prepare the project report and hence 'not satisfied'. Most of them prepared project report by paying necessary fees.

A few respondents of Khadi and Village Industries Board express their views that, they could not understand the lectures given by resource persons because of their own language problem

TABLE-7; MAJOR EXPECTATION AND EXTENT OF THEIR FULFILLMENT FROM EDPS

\begin{tabular}{|c|c|c|c|c|c|}
\hline \multicolumn{6}{|c|}{ Table-8: Major expectation and extent of their fulfillment from EDPS } \\
\hline $\begin{array}{l}\text { Sl. } \\
\text { No. }\end{array}$ & Expectation & Satisfied & $\begin{array}{c}\text { Satisfied } \\
\text { to } \\
\text { some extent }\end{array}$ & $\begin{array}{c}\text { Not } \\
\text { satisfied }\end{array}$ & Frequency \\
\hline 1. & $\begin{array}{l}\text { Expected knowledge about starting an enterprise } \\
\text { or taking up economic activity }\end{array}$ & 44 & 71 & 42 & 157 \\
\hline 2 & Expected knowledge about MSME/SSI & 66 & 54 & 37 & 157 \\
\hline 3 & Expected knowledge about Finance & 89 & 48 & 20 & 157 \\
\hline 4 & Expected assistance in selecting a project & 26 & 55 & 76 & 157 \\
\hline 5 & Expected marketing support & 28 & 48 & 81 & 157 \\
\hline 6 & Expected knowledge of technical know-how & 28 & 10 & 119 & 157 \\
\hline 7 & Expected grant of subsidy & 54 & 24 & 79 & 157 \\
\hline 8 & Expected knowledge of managing an enterprise & 40 & 54 & 63 & 157 \\
\hline 9 & Expected knowledge about incentives & 46 & 42 & 69 & 157 \\
\hline 10 & $\begin{array}{l}\text { Expected knowledge about project report } \\
\text { preparation }\end{array}$ & 39 & 53 & 65 & 157 \\
\hline
\end{tabular}

Source: Filed survey

From the above analysis on major expectation and their fulfillment from Entrepreneurship Development programme it was found that rural entrepreneurs in the group satisfied and satisfied to some extent on many grounds was much higher than entrepreneurs in the satisfied group. So it can be concluded from the above analysis that various entrepreneurship development programmes attended by 157 rural entrepreneurs on various grounds are not adequate to motivate rural entrepreneurs. The working hypothesis formed was correct and proved.

\section{Conclusions And Suggestions}

Entrepreneurship is the outcome of interaction of the individual, environment with socio-cultural factors. It has been recognized on the basis of many experiments that entrepreneurship can be induced. The Government having recognized this is making numerous efforts to inculcate a spirit of enterprise among its people. Entrepreneurship is the one of the best ways of improving the socio-economic status of rural entrepreneurs in society. The following suggestions can be put forwarded for the protection and enhancement of demand potentiality leading to fertile ground for rural entrepreneurship. Entrepreneurship would be conducive for rural capacity utilization and development and solving rural problems like, unemployment, poverty, low level standard of living etc. 
* Entrepreneurship development training should be directed not only to motivate but also to instill confidence in the trainees. The trainees should be made aware that failure is inevitable but success is possible if they pursue with determination. An environment and culture that tolerates initial failures should be created.

* It is also not necessary that one should belong to a particular caste or community to become an entrepreneur. The more important is proper mindset. So change of mindset is an important step for developing entrepreneurial environment in rural areas. Organisations may organize camp in village areas for the benefit of rural people.

* It is also equally important that an entrepreneur will have to take up responsibility for their own continuous learning and re-learning for their development.

* In the present context, Entrepreneurship Development Programme could be more pro-active, broadbased (in terms of target group) and of a continuous nature.

* The influence of success stories of entrepreneurs has recognized as another important factor for facilitating entrepreneurship. Hence there is a need for introduction of such success stories of entrepreneurship among those who have not even completed high school are to be put in front of graduates to instill confidence. Success stories not only generate entrepreneurship but also quality.

* Training institutions like Institutes of Entrepreneurship Development (IEDS) and centres for entrepreneurship development (CEDS) should be established to organize training programmes in rural areas. There is a need to enlighten the rural entrepreneurs on the various management skills.

* Formation of village development council, under the guidance of appropriate Government, at the village level .This council should lead in forming and propagating about negative impacts of drain of rural demand, rural resources to urban area. Such a village development council will be forum where issues relating development will be discussed and opinions will be floated among the people for course of action.

* Intensive follow-up services have to be provided to the entrepreneurs in the post-training phase so that the trained entrepreneurs are able to pursue the activities on a sustainable basis.

* Formation of Rural entrepreneurship Development Bank of India, on the line of Industrial Development bank of India, is essential to promote entrepreneurship in the rural areas. It role would be to make available finance, knowledge, technical expertise, managerial advice, help in marketing, string etc. it has to take case from beginning to end. Even its role would be to come up with plans.

* Careful selection and proper planning of the project are also important to the success of the enterprise. A fair degree of knowledge of the proposed project is essential to meet any uncertainty that may arise later.

\section{Conclusion}

Entrepreneurship plays a vital role in the growth of our economy. It acts as a catalyser in fostering the initiative to undertake economic activities for the production and distribution of wealth. In rural areas larger amount of potential, remain untapped due to lack of supportive means and management. Proper entrepreneurial skill and marketing talent are to be given to rural entrepreneurs through proper training programmes for carrying entrepreneurial activities. What the rural micro entrepreneurs need is encouragement and support from the family members, government and societies. These rural entrepreneurs must be involved in modern small scale units. If they are properly trained and provided with the required capital rural India and informal sector will develop, and this, in turn, will reduce the migration of rural people to urban areas in search of livelihood.

\section{Limitation}

The findings of this study were based only on descriptive, lower-level statistics. Further research is thus needed to gain more insight into the unique challenges facing rural entrepreneurs and their training and development needs. It is recommended that more advanced statistical procedures, such as regression, factor analyses, and anova should be utilised in the further development of the knowledge base to truly understand the dynamics of rural entrepreneurship

\section{References}

[1] Banerjee G.D and Banerjee Srijeet(2012), "Rural entrepreneurship Development programme in India, an impact assessment.abhijeet publications, New Delhi

[2] Banerjee Gangadhar (2010), "Rural entrepreneurship Development programme -An impact assessment", Bengal Economic Association, $30^{\text {th }}$ annual Conference (2010) number.

[3] Desai,Vasant.(2009).Fundamentals of Entrepreneurship and Small Business Management, Himalaya Publishing House.

[4] Economic Survey, Assam, 2011-12, available at http://ecocstatassam.nic.in/ ads_economic\%20survey.pdf. Accessed on May 25, 2012.

[5] Khanka S S (2009), "Motivational Orientation of Assamese Entrepreneurs in the SMESector", Journal of Entrepreneurship, Vol. 18, No. 2, pp. 209-218. 


\section{A Study on Impact of Motivational Factors on the Growth of Rural Entrepreneurs Of Assam}

[6] Khanka S S (2009), "Motivational Orientation of Assamese Entrepreneurs in the SMESector", Journal of Entrepreneurship, Vol. 18, No. 2, pp. 209-218.

[7] Kanitkar Ajit (1994), "Entrepreneurs and Micro-Enterprises in Rural India”, Economic and Political Weekly, Vol. 29, No. 9, pp. 2530.

[8] KulawczukPrzemyslaw, Development of osi.hu/publications/books/kimball/kimbpdf.Accessed on march,10,2010

[9] Kaippachery,Sudheesh(2005), "Reforms and its impact on the SSIs :Afield appraisal",Journal on Rural development,vol.24,no.2,pp.213-226

[10] KumarJyotiandLalhunthara(2012).“socio-economic background of micro Entrepreneurs in Aizawal District,Mizoram." SEDME ,vol.39.no.2.June ,pp-1-17

[11] Mishra,B.B. and K.Bal(1997)." Women Entrepreneurs in Orissa,A study of their Profile, Motivation and constraints", Indian Journal of Commerce.1.193,part 4:385

[12] Mandal Ramakrishna (2008), Khadi and Village Industries in North East India with Special Reference to Arunachal Pradesh: Retrospect and Prospect, IUP, Hyderabad.

[13] MSMED Act 2006, Ministry of Small Scale Industries, Notification, July 18, 2006, Government of India

[14] Mohanty Sangram Keshari(2006) “Fundamentals of Entrepreneurship", Prentice Hall Of India, New Delhi

[15] Nath Dwaraka H.D.(2013). "Strategies for employment generation in Rural India- a critical evaluation.” kurukshetra, vol.61,no.4, pp.27-31.

[16] Nicola Mecchari,and Gianluigi Pelloni,"Rural entrepreneurs and institutional assistance: an empirical study from mountainous Italy”, Entrepreneurship \& Regional Development, Volume 18, Issue 5 September 2006 , pages 371 - 392 ; Available atwww.informaworld.com/smpp/.../title $\mathrm{db}=$ all content $=\mathrm{g} 755323002$ (Accessed on march, 09, 2010)

[17] Orhan M. and D. Scott (2001)," Why Women Enter in to Entrepreneurship: An Exploratory Model”. Women in Management review, 16.5:232-43.

[18] Srivastav Nirankar \& Syngkon Rickey A. J(2008), "Emergence of Small Scale Industries and Entrepreneurship in the RuralAreas of Northeastern States of India: An Analytical.” The Icfai University Journal of Entrepreneurship Development, Vol. V, No. 2, pp. 62

[19] Sophia Stathopoulou Demetrios Psaltopoulos and Dimitris Skuras, "Rural Entrepreneurship in Europe: A Research Framework and Agenda",. International Journal of Entrepreneurial Behaviour \& Research, 2004, Vol. 10, Issue 6, p. 404-425 2004. Available at SSRN: http://ssrn.com/abstract=1500942(Accessed on march, 06, 2010)

[20] Sarri K and A. Trihopoulou (2005)," Female Entrepreneurs' Personal Characteristics and Motivation: A review of the Greek Situation", women in Management Review.20, 1:24-36.

[21] Sinha Harendra (2010), "Block administration without panchayat raj institutions: An assessment in to the lunglei district of Mizoram,"kurukshetra, vol.58,no.12, pp.44-47

[22] Santana Krishnan R and Jegadeesan G (2008), Entrepreneurship and Rural Developmentin India, IUP, Hyderabad

[23] Sharmina Afrin, Islam Nazrul and Uddin, Shahid(2008) "A multivariate model of micro credit and rural women entrepreneurship development in Bangladesh": International Journal of business and management, Available at www.ccsenet.org/ journal /index.php ijbm/article/view/1360,(Accessed on march, 10,2010) 